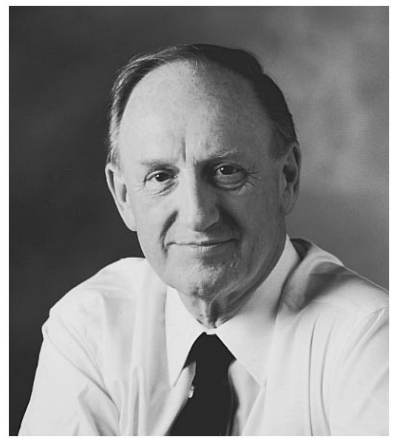

\section{A Special Section}

This month, we include a small special section that covers the broad nature of infrared radiometric sensor calibration. Guest editor Alan Thurgood has selected a sampling of papers from the annual symposium on Infrared Radiometric Sensor Calibration that is hosted by the Space Dynamics Laboratory at Utah State University and the National Institute of Standards and Technology (NIST). The latest of these symposia was held 13-15 May 1997. The goal of the symposium is to provide a forum for those engaged in the calibration and evaluation of infrared radiometric sensors. Participants are provided the opportunity to share ideas and focus on calibration issues pertinent to an extensive range of disciplines that address both environmental and defense needs. The results obtained with today's sophisticated instruments can be no better than the quality of the calibration. These nine papers reflect some of the essential aspects of the calibration process. We thank the authors of this special section for bringing this field to the attention of and into focus for our readers.

\section{The Penultimate Editorial}

Eighty-one editorials down and two more to go. So this is my penultimate editorial. In case you do the calculation to check me out I need to tell you that I did miss one editorial. People do check my arithmetic apparently. One of our most senior members sent an e-mail message to SPIE headquarters addressed to all the senior staff plus a few others. The message, dated 20 February 1997, read in part as follows:

"Would someone be kind enough to forward this to Brian Thompson? I can't find his email address.

Upon receiving Optical Engineering, I always read the interesting editorial. I was interested to see in the February issue that someone made a booboo adding up the numbers in Table 2 . The sum on the numbers given is 373 papers and not 470 as printed. We shouldn't let it get around that SPIE can't add...
Brian always writes good editorials, and I think that we should have given an "editorial test" to prospective candidates for the new editor's job."

The e-mail letter was timed at 9:00 a.m. By 11:07 a.m. the writer sent a second message which read:

" After I sent my message about the arithmetic error in the February issue of Optical Engineering, a colleague pointed out to me that the numbers next to the name of more than one country probably meant that number applied to $\mathrm{EACH}$ of the countries. ...Duh!...,

The important part of the message for me was that it pointed out that people do read the journal including the editorials. In this same vein I received the following letter that the author has allowed me to reprint in this column with attribution.

\author{
Dr. Brian J. Thompson \\ Optical Engineering Office \\ 692 Mt. Hope Ave. \\ Rochester, NY 14620
}

\section{Dear Provost Thompson:}

Before you step down from the position of Editor, I'm writing to let you know that I've enjoyed reading your monthly editorials in Optical Engineering. The precise timing of this letter is prompted, though, by your comments in the May issue on the use of the word "scotch" and my recent trip to our company store. With this letter, I hope you will find several items labeled Scotch ${ }^{\mathrm{TM}}$ that might persuade you to use the term for things other than the beverage! In addition to the usual sampling, I've included some Scotchlite ${ }^{\mathrm{TM}}$ Reflective Sheeting in familiar colors. I figure tacking "light" on the end will have a positive influence.

As I understand the history of one of our bestknown trademarks, Minnesota Mining and Manu- 
facturing's early forays into the tape market included a masking tape with adhesive on only the edges. The purpose of the minimal adhesive was to reduce manufacturing costs. Apparently, the product was unsuccessful and earned the descriptor "scotch" from customers who thought the company was being stingy with its adhesive. In response, the company stopped the practice but turned the adjective into a trademark, one that we hope has come to mean quality and value for the dollar.

Enough company history and shameless promotion. I wish you a pleasant Rochester summer, and I thank you for the day-brightening editorials and anecdotes that have been part of your superb stewardship of the journal.

Best wishes,

Madeleine Beal Fleming

Optics Specialist

3M Traffic Control Materials Lab.

For those readers who would like further details of this small piece of history, Madeleine refers us to the $3 \mathrm{M}$ web page (http://www.mmm.com). As she pointed out to me in a subsequent letter, she didn't have the story exactly right but close enough.

\section{The Penultimate Editor's Anecdote}

I remember when I was appointed Provost of the University of Rochester in 1984, one of the eager and very supportive editors of the student newspaper wrote that I was "the penultimate choice for Provost." He was trying to pay me more than the ultimate compliment! So much for education. I took it in the real spirit of his intent.

I enclose the following pair of letters without comments. The first is from me to an author; the second is his response.

I am pleased to acknowledge the receipt of your manuscript entitled , which you wish to be considered for publication in Optical Engineering.
Your paper has been assigned the control number $\mathrm{OE} \operatorname{xxxxx}$. Please refer to this number in any correspondence.

Your paper appears to be identical to a proceedings paper $(\mathrm{xxxx}-\mathrm{xx})$. As you are perhaps aware, I cannot consider this manuscript for publication if it is identical (see attached editorial).

I will hold the paper until I hear from you.

$$
\text { Sincerely, }
$$

Brian J. Thompson Editor, Optical Engineering

Dear Prof. Thomson,

\section{Re: Paper OE xxxxx}

Thank you for your letter of 18th Sept. 96, hinting that my article may go to hell, since it is nearly the same as that of the one submitted to SPIE proceedings. May I submit that you only clarified that there are two journals some of SPIE proceedings and the other the Journal Optical Engineering and the articles should be completely different.

I now feel happy that it has gone to the correct expert as your kindself, and the constructive criticism so that it can be re-written, edited and that it will be as good as your article, may be sent to me. You need not send the manuscripts back.

Sincerely,

Finally, I received several responses to my "beer mat" quote of Debussy. So here is the other side of that beer mat.

SID VICIOUS

Brian J. Thompson Editor 